\title{
Retardation of Associative Learning in the Rabbit by an Adenosine Analog as Measured by Classical Conditioning of the Nictitating Membrane Response
}

\author{
Lois Winsky and John A. Harvey \\ Departments of Psychology and Pharmacology, The University of lowa, lowa City, lowa 52242
}

\begin{abstract}
A series of 5 experiments examined the effects of the adenosine agonist, $N^{6}$-( L-phenylisopropyl) adenosine (L-PIA) and its isomer, D-PIA, on the acquisition of conditioned responses in the rabbit. Extension of the nictitating membrane was classically conditioned to a tone and light stimulus presented for $800 \mathrm{msec}$ before delivery of a 100 msec shock - the unconditioned stimulus - to the skin over the paraorbital region of the head. L-PIA $(5.0 \mu \mathrm{mol} / \mathrm{kg})$ retarded the rate of acquisition of conditioned responses to both the tone- and light-conditioned stimuli, while D-PIA, at doses of 5.0 and $10.0 \mu \mathrm{mol} / \mathrm{kg}$, had no significant effect. Control experiments employing the explicitly unpaired presentations of tone, light, and shock stimuli indicated that the retarded acquisition of conditioned responses produced by L-PIA was due to an action on associative learning. L-PIA had no effect on the threshold of the shock's eliciting of the unconditioned response nor on the amplitude of the elicited response, but produced a large and significant reduction in the ability of the tone-conditioned stimulus to evoke conditioned responses. It was concluded that L-PIA blocked the rate of associative learning by decreasing the excitatory properties of conditioned stimuli. These effects of L-PIA suggest that endogenous adenosine may act to modulate the rate of associative learning.
\end{abstract}

Adenosine has been shown to produce a large number of physiological and biochemical effects in the CNS. For example, adenosine and its analogs depress both spontaneous and evoked neuronal firing (Phillis and Kostopoulos, 1975; Phillis et al., 1979), inhibit the release of several neurotransmitters, including norepinephrine, dopamine, serotonin, ACh, GABA, glutamatc, and aspartate (Corradetti et al., 1984; Fredholm and Hedqvist, 1980; Jonzon and Fredholm, 1984; Murray et al., 1982), and can both decrease and increase adenylate cyclase activity, depending on the brain region and dose administered (Londos et al., 1980; van Calker ct al., 1979). Adenosine-uptake inhibitors also depress neural activity and transmitter release and potentiate these same effects of exogenously applied adenosine (Jonzon and Fredholm, 1984; Phillis and Kostopoulos, 1975), which suggests that endogenous adenosine may be an important modulator of neural activity within the CNS. Xanthine derivatives such as caffeine and theophylline reverse the inhibitory effects of adenosine and uptake inhibitors on neural activity and transmitter release, an indication that these actions of adenosine are mediated via specific receptors (Jonzon and Fredholm, 1984;

\footnotetext{
Received Feb. 18, 1986; revised Apr. 11, 1986; accepted Apr. 17, 1986.

This work was supported by USPHS Grant MH6841 and National Science Foundation Grant BNS \#83-09826. L.W. was supported by USPHS Training Grant MH15773.

Correspondence should be addressed to Dr. John A. Harvey, Department of Psychology, SSH, E-117, The University of Iowa, Iowa City, IA 52242.

Copyright (C) 1986 Society for Neuroscience 0270-6474/86/092684-07\$02.00/0
}

Murray et al., 1982; Phillis and Kostopoulos, 1975; Phillis et al., 1979).

Two extracellular adenosine receptors, labeled $\mathrm{A} 1$ and $\mathrm{A} 2$, which may be distinguished by the differential binding affinities of adenosine and its analogs (Dunwiddie and Fredholm, 1984; Goodman and Snyder, 1982; Londos et al., 1980; van Calker et al., 1979), have been proposed. On the basis of a comparison of the differential binding affinities of adenosine and its analogs, with their potencies on physiological and neurochemical processes, the high-affinity Al receptor has been linked with the inhibition of neuronal firing, transmitter release, and inhibition of adenylate cyclase activity, while the low-affinity A2 receptor appears to be related only to the activation of adenylate cyclase (Dunwiddie and Fredholm, 1984; Londos et al., 1980; Snyder, 1985; van Calker et al., 1979; Wojcik and Neff, 1983).

The behavioral effects of adenosine analogs have also been examined. Centrally or peripherally administered adenosine analogs produce decreases in locomotor activity (Snyder et al., 1981; Vapaatalo et al., 1975), decrease schedule-controlled responding (Glowa and Spealman, 1984; Logan and Carney, 1984), display anticonvulsant activity (Dunwiddie and Worth, 1982), and influence sleep patterns (Radulovacki et al., 1982). Xanthine derivatives have also been shown to antagonize these behavioral actions of adenosine analogs (Logan and Carney, 1984; Radulovacki et al., 1982; Snyder et al., 1981).

A number of drugs that are assumed to act on different transmittersystemsemploying ACh,dopamine, serotonin, and opioids have been reported as retarding or enhancing the rate of associative learning, as measured by classical (Pavlovian) conditioning of the nictitating membrane response of the rabbit (Harvey and Gormezano, 1986; Schindler et al., 1985). The growing evidence that adenosine may be an important endogenous modulator of a large number of neural systems, employing a variety of synaptic transmitters (Daly, 1979; Fredholm and Hedqvist, 1980), suggests that adenosine or its analogs might also influence learning. To examine this possibility, we employed the adenosine analog, $N^{6}$-(phenylisopropyl) adenosine (L-PIA), which shares many of the actions of adenosine but is resistant to deamination and, therefore, can be injected systemically to produce its central effects (Katims et al., 1983). Five experiments were carried out. First we used the paired presentations of conditioned stimuli (CSs) and a shock-unconditioned stimulus (UCS) to determine the effects of a range of doses of L-PIA on the acquisition of conditioned responses (CRs) to both tone and light CSs. Second, to further characterize the actions of L-PIA, we examined the effects of its diastereoisomer, D-PIA, on CR acquisition. Third, we presented explicitly unpaired tone, light, and shock stimuli of the first and second experiments to determine whether L-PIA had any effect on nonassociative responding or on the unconditioned response (UCR) to the shock UCS. Fourth, in order to further examine whether the effects of L-PIA on CR acquisition might be mediated by effects on the uncon- 
ditioned nictitating membrane reflex, we employed a range of UCS intensities to determine UCS thresholds and amplitudes. Fifth, we examined whether the effects of L-PIA on CR acquisition might be mediated by effects on the intensive properties of the CS, as has been shown for other drugs that affect learning (Schindler et al., 1985). This was accomplished by measuring, in previously trained animals, the effects of L-PIA on the percentage of occurrence of CRs as a function of the tone CS intensity.

\section{Materials and Methods}

\section{Subjects}

This study employed a total of 194 male and female rabbits (New Zealand white albino), weighing approximately $2 \mathrm{~kg}$ on arrival from Iowa Ecology Farms (Wilton, IA). All animals were housed individually with free access to rabbit chow and water.

\section{Apparatus and general procedure}

The apparatus and procedure for delivery of stimuli and recording movements of the nictitating membrane have been described in detail (Gormezano, 1966; Gormezano et al., 1983; Harvey et al., 1985). In general, groups of 12 rabbits were trained at one time. Each rabbit was placed in an individual Plexiglas restrainer, fitted with a headmount, and placed into 1 of 12 individually ventilated and sound-attenuated experimental chambers. A phototransistor assembly, attached to the headmount and directly coupled to a loop of nylon that had been sutured into the right nictitating membrane, converted membrane movements into electrical signals that were subjected, using an Apple II/FIRST computer system (Scandrett and Gormezano, 1980), to an analog-todigital analysis using a 5 msec sampling rate (unless otherwise noted) and having a resolution of $0.06 \mathrm{~mm}$ of actual membrane movement. The digitized values were logged on a Corvus (IMI-7710) for subsequent statistical analysis. The Apple II/FIRST computer system also controlled the delivery of 3 stimuli to each rabbit. Unless otherwise noted, these stimuli were an $800 \mathrm{msec}, 84 \mathrm{~dB}\left(2 \times 10^{-4} \mathrm{dyn} / \mathrm{cm}^{2}\right.$ reference $), 1$ $\mathrm{kHz}$ tone delivered by an audio-oscillator (Hewlett-Packard 201CR) through an $11.4 \mathrm{~cm}$ speaker positioned above and in front of the animal; an $800 \mathrm{mscc}, 10 \mathrm{~Hz}$ flashing of 2 housc lights positioncd on cither side of the speaker to yield a change in illumination, as measured at the eye level of the rabbit, from 32.0 to $8.0 \mathrm{~lx}$; and a $100 \mathrm{msec}, 3 \mathrm{~mA}, 60 \mathrm{~Hz}$ shock delivered through 2 electrodes located $10 \mathrm{~mm}$ posterior to the canthus.

\section{Drugs}

L-PIA $\left(M_{\mathrm{r}}=385.4\right)$ and its diastereomer, D-PIA, were obtained from Boehringer Mannheim (Indianapolis, IN). Solutions of L- or D-PIA were prepared fresh daily by dissolving the drug in a small volume of $0.2 \mathrm{~N} \mathrm{HCl}$, back-titrating to $\mathrm{pH} 5.5$, and diluting to the appropriate concentration with sterile physiological saline. Solutions of the vehicle were prepared in an identical manner. Fifteen minutes prior to testing, $2 \mathrm{ml} / \mathrm{kg}$ of all doses of drugs or vehicle was injected subcutaneously between the shoulder blades.

\section{Paired CS-UCS training}

Paired CS-UCS training was carried out in 2 separate studies, each of which employed experimentally naive rabbits. One day after placement of sutures into the nictitating membrane, the 81 animals of the first study received a 60 min adaptation session, during which no stimuli were delivered and no drug or vehicle injected. However, in order to obtain a measure of baseline responding, extensions of the nictitating membrane were recorded during the observation intervals to be used during conditioning. On the day after adaptation, animals were randomly assigned to 1 of 7 injection conditions, consisting of L-PIA doses $(\mu \mathrm{mol} / \mathrm{kg})$ of 0 (vehicle control; $n=12), 0.005(n=12), 0.05(n=11)$, $0.5(n=12), 1.0(n=12), 2.5(n=12)$, or $5.0(n=10)$. Injections of L-PIA or its vehicle occurred $15 \mathrm{~min}$ prior to each of 10 daily $(60 \mathrm{~min})$ acquisition sessions. Each acquisition session consisted of 60 trials composed of 30 tone-shock and 30 light-shock pairings presented in a randomized sequence within 10-trial blocks, with the restriction that there be no more than 3 consecutive tone- or light-shock trials in each block. On each trial, the offset of the $800 \mathrm{msec}$ tone or light CS occurred simultaneously with the onset of the 100 msec shock UCS. Trials oc- curred at mean intertrial intervals of $60 \mathrm{sec}$ (range, $50-70 \mathrm{sec}$ ). A response was defined as a $0.5 \mathrm{~mm}$ or greater extension of the nictitating membrane and its onset latency was measured from the time of CS onset. Responses were recorded as CRs if they were initiated during the $800 \mathrm{msec}$ presentation of the tone or light CS, and as UCRs if response initiation occurred after shock onset.

The 44 rabbits in the second study were treated in exactly the same manner, except that on the day after adaptation animals were divided into 4 groups of 11 animals each and injected with either vehicle, L-PIA $(5.0 \mu \mathrm{mol} / \mathrm{kg})$, D-PIA $(5.0 \mu \mathrm{mol} / \mathrm{kg})$, or D-PIA $(10.0 \mu \mathrm{mol} / \mathrm{kg})$.

\section{Unpaired stimulus training}

Twenty-four experimentally naive rabbits received a 60 min adaptation session carried out exactly as described above, and $1 \mathrm{~d}$ later were divided randomly into 2 injection groups, with 12 rabbits receiving vehicle and 12 rabbits receiving L-PIA $(5.0 \mu \mathrm{mol} / \mathrm{kg}) 15 \mathrm{~min}$ prior to each of 10 daily, 60 min sessions. Each daily session consisted of 120 trials composed of 30 tone-alone, 30 light-alonc, and 60 shock-alone trials presented in a randomized sequence within 20-trial blocks, with the restriction that no more than 3 tone, light, or shock trials occur consecutively. The tone, light, and shock stimuli were identical with those described previously. Trials occurred at mean intertrial intervals of 30 $\mathrm{sec}$ (range, 25-35 sec). Responses were recorded if they occurred during the $800 \mathrm{msec}$ presentation of tone and light stimuli, or after shock onset. In addition, responses occurring during the $800 \mathrm{msec}$ prior to shock onset, when no other stimuli had been presented, were recorded as baseline responses. Finally, the peak amplitude and onset latency of each response to shock were also recorded.

\section{Determination of the shock-UCS threshold for elicitation of UCRs}

Twenty-four experimentally naive rabbits received a $35 \mathrm{~min}$ adaptation session, as described above, and $1 \mathrm{~d}$ later were divided into 2 injection conditions, with 12 rabbits receiving vehicle and 12 rabbits L-PIA (5.0 $\mu \mathrm{mol} / \mathrm{kg}$ ) $15 \mathrm{~min}$ prior to each of 3 daily $(35 \mathrm{~min}$ ) sessions. Each session consisted of 35 shock-alone trials in five 7-trial blocks. Seven shock intensities, of $0.25,0.50,0.75,1.0,2.0,3.0$, and $4.0 \mathrm{~mA}$, were randomly presented within each 7 -trial block. The intertrial interval was randomly generated with a mean of $60 \mathrm{sec}$ (range, 50-70 sec). Data were sampled at $2 \mathrm{msec}$ intervals during each trial. Responses occurring within 600 msec of shock onset were recorded, along with their onset latencies and peak amplitudes.

\section{Determination of the tone-CS threshold for elicitation of CRs}

Experimentally naive rabbits $(n=21)$ received one $60 \mathrm{~min}$ adaptation session, followed by $7 \mathrm{~d}$ of acquisition training carried out exactly as described for paired CS-UCS training, except that only a tone CS was employed, and animals were not injected with vehicle or drug. Thus, each of the daily $(60 \mathrm{~min})$ sessions consisted of 60 pairings of the 84 $\mathrm{dB}$ tone CS with the $3 \mathrm{~mA}$ shock UCS. On the day after the last acquisition session, rabbits were randomly divided into 2 groups and injected with either vehicle $(n=10)$ or $5.0 \mu \mathrm{mol} / \mathrm{kg}$ L-PIA $(n=11) 15$ min prior to 1 additional $(60 \mathrm{~min})$ session. During this last session, the intensity of the tone CS was randomly varied over 60 paired CS-UCS trials. The 60 trials were divided into six 10-trial blocks, consisting of the following 10 intensities of the tone $\mathrm{CS}(\mathrm{dB}): 0,45,50,55,60,65$, $70,75,80$, and 84 . On trials when no tone was presented $(0 \mathrm{~dB})$, the level of responding observed during the $800 \mathrm{msec}$ prior to UCS delivery provided a measure of the baseline rate of responding. For all other trials, responses were recorded as CRs if they occurred during the 800 msec presentation of the CS, and as UCRs if they occurred after shock onset.

\section{Statistics}

A repeated-measures analysis of variance was performed on the data of each experiment, with follow-up analyses of significant effects carried out by the method of Dunnett (Winer, 1971). For all statistical comparisons, a value of $p<0.05$ was considered to be significant.

\section{Results}

\section{$L-P I A$ produces a stereoselective retardation of $C R$ acquisition} In the first acquisition study, L-PIA produced a significant $(p<$ $0.01)$ retardation in $C R$ acquisition, as measured by both the 


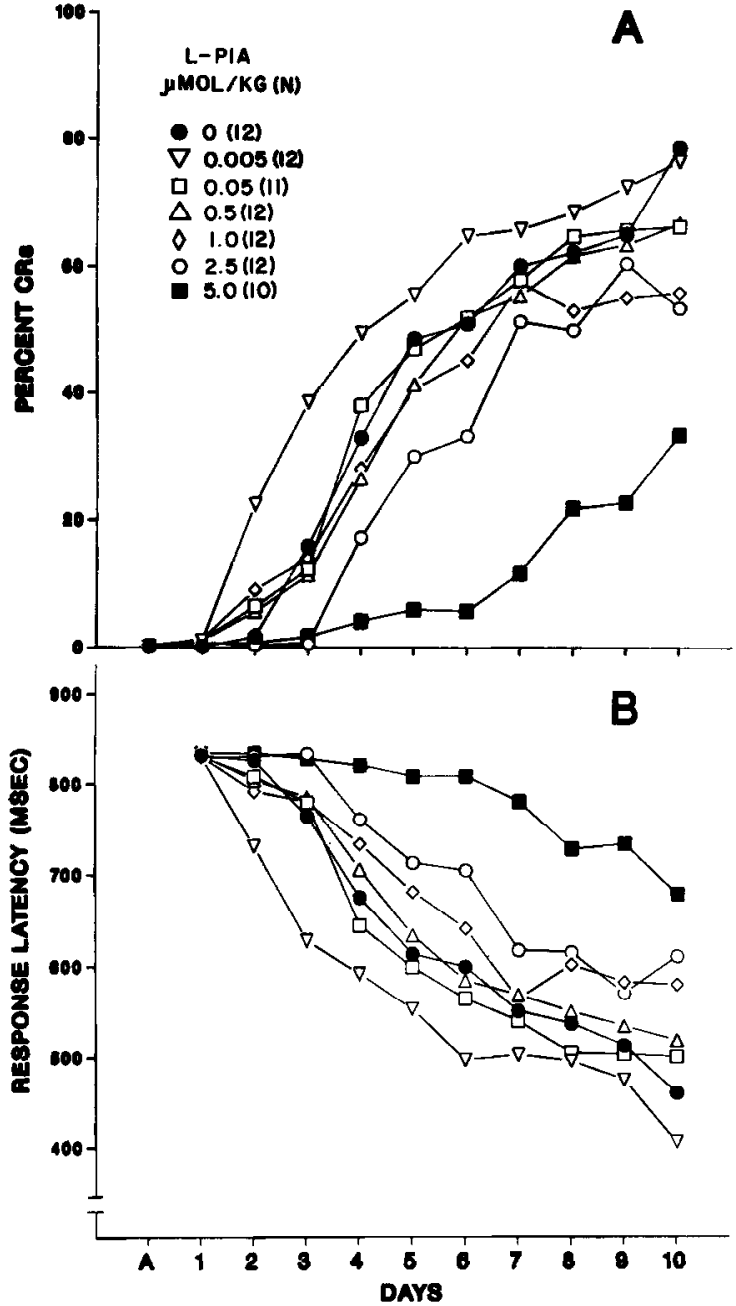

Figure 1, Effects of L-PIA on acquisition of CRs during the paired CS-UCS training in experiment 1. Data are expressed as mean percentages of conditioned responses $(A)$ and response-onset latencies $(B)$ during tone and light CS trials combined for rabbits receiving subcutaneous injections of the specified doses of L-PIA or vehicle 5-15 min prior to each of 10 daily $60 \mathrm{~min}$ training sessions. The number of animals at each dose is given in parentheses.

percentage occurrence of CRs (Fig. 1A) and response-onset latency (Fig. 1B). There was no differential effect of L-PIA on CR acquisition to tone, compared with light, CSs, as indicated by the absence of a significant dose $\times$ modality interaction. A significant dose $\times$ days interaction $(p<0.001)$ indicated that L-PIA had also retarded the rate of $C R$ acquisition across the $10 \mathrm{~d}$ of training. Follow-up analyses indicated that the retarded acquisition was significant only for the $5.0 \mu \mathrm{mol} / \mathrm{kg}$ dose of L-PIA $(p<0.05)$.

In a second acquisition study, the cffects of $5.0 \mu \mathrm{mol} / \mathrm{kg} \mathrm{L}-\mathrm{PIA}$ were contrasted with those of 5.0 and $10.0 \mu \mathrm{mol} / \mathrm{kg}$ of D-PIA; these results are shown in Figure 2. In agreement with the data presented in Figure 1, L-PIA $(5.0 \mu \mathrm{mol} / \mathrm{kg})$ produced a significant $(p<0.001)$ retardation in CR acquisition, as measured by both the percentage of CRs (Fig. $2 A$ ) and the response-onset latency (Fig. $2 B$ ). In contrast, doses of 5.0 or $10.0 \mu \mathrm{mol} / \mathrm{kg}$ of D-PIA had no significant effect on either measure of CR acquisition.

In order to compare the results of the first and second acquisition study as a function of drug dosage, we calculated the average percentage of CRs at each dose of drug or vehicle,

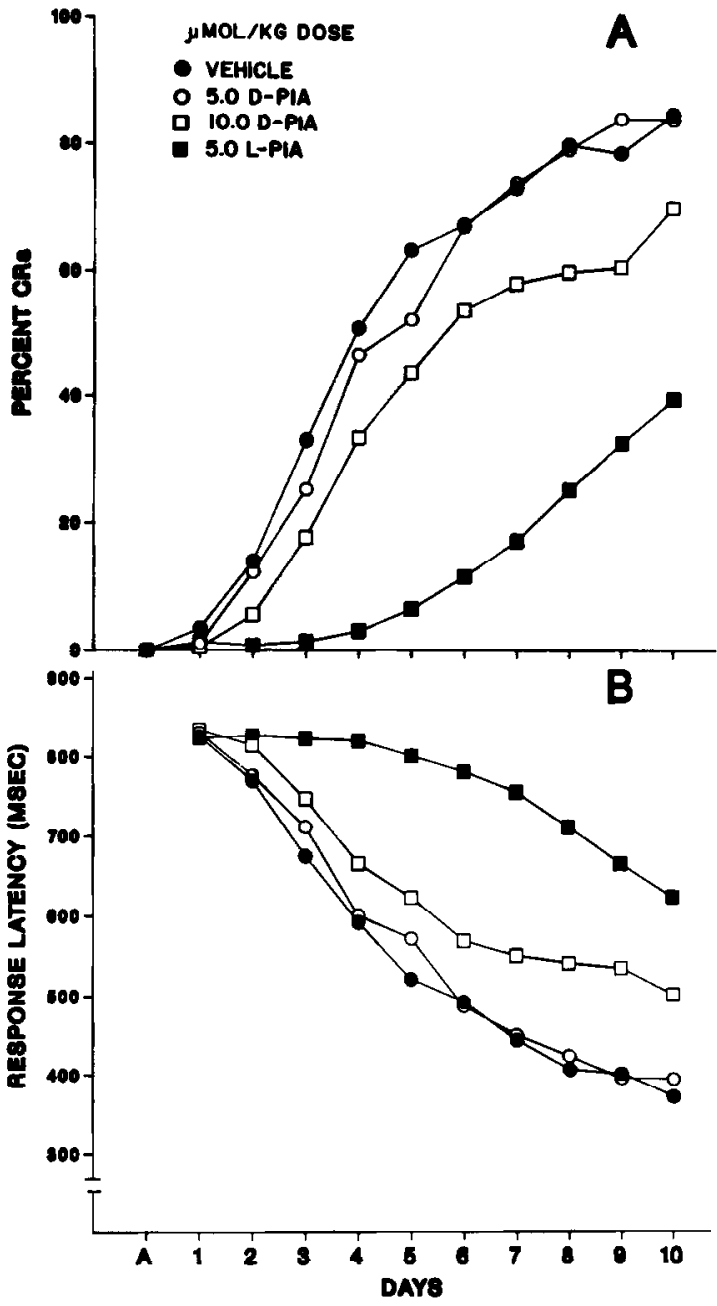

Figure 2. Comparison of the effects of $5.0 \mu \mathrm{mol} / \mathrm{kg}$ L-PIA with effects of $0,5.0$, and $10.0 \mu \mathrm{mol} / \mathrm{kg}$ D-PIA during the paired CS-UCS training in experiment 2. Data are expressed as mean percentage of conditioned responses $(A)$ and response latencies $(B)$ during tone and light $C S$ trials combined. Rabbits received subcutaneous injections 5-15 min prior to each of the 10 daily sessions. All points are the means of data from 11 rabbits.

collapsed across all $10 \mathrm{~d}$ of acquisition training and irrespective of CS modality. The frequency of CRs occurring at each dose of drug was then expressed as a percentage change from that of the appropriate vehicle controls; these values are presented in Table 1. In the first study, the lowest dose of L-PIA $(0.005$ $\mu \mathrm{mol} / \mathrm{kg}$ ) produced a $24 \%$ increase in CR occurrence during acquisition training, which was, however, not significant. Increasing doses of L-PIA produced a correspondingly greater percentage decrease in CR occurrence during acquisition. The highest dose of L-PIA $(5.0 \mu \mathrm{mol} / \mathrm{kg})$ produced a large (74\%) and significant $(p<0.01)$ decrease in CRs. This effect was replicated in the second study, where $5.0 \mu \mathrm{mol} / \mathrm{kg}$ L-PIA also produced a large $(76 \%)$ decrease in CRs $(p<0.01)$. In contrast, an equimolar dose of D-PIA $(5.0 \mu \mathrm{mol} / \mathrm{kg})$ produced only a small $(4 \%)$ and nonsignificant effect on CRs. Even a higher dose of 10.0 $\mu \mathrm{mol} / \mathrm{kg}$ D-PIA produced only a $26 \%$ dccrease in CRs, which was also not significant.

\section{$L-P I A$ does not affect responding during unpaired CS and UCS training}

The level of responding to the tone and light stimuli across the $10 \mathrm{~d}$ of explicitly unpaired presentations of these stimuli was 
Table 1. Effect of L-PIA and D-PIA on CR acquisition expressed as percentage change in CRs from mean of vehicle control

\begin{tabular}{lcc}
$\begin{array}{l}\text { Drug and dose } \\
(\mu \mathrm{mol} / \mathrm{kg})\end{array}$ & $N$ & $\begin{array}{l}\text { Percentage change } \\
\text { Mean } \pm \text { SEM }\end{array}$ \\
\hline Study 1 & 12 & $0 \pm 14.9$ \\
Vehicle & 12 & $123.7 \pm 19.5$ \\
L-PIA 0.005 & 11 & $-1.1 \pm 20.4$ \\
L-PIA 0.05 & 12 & $-7.4 \pm 15.8$ \\
L-PIA 0.50 & 12 & $-13.6 \pm 16.4$ \\
L-PIA 1.00 & 12 & $-28.7 \pm 11.8$ \\
L-PIA 2.50 & 10 & $-74.0 \pm 10.3^{b}$ \\
L-PIA 5.00 & & $0 \pm 12.8$ \\
Study 2 & 11 & $-74.5 \pm 7.1^{b}$ \\
Vehicle & 11 & $-4.1 \pm 10.4$ \\
L-PIA 5.00 & 11 & $-26.5 \pm 13.3$ \\
D-PIA 5.00 & 11 &
\end{tabular}

${ }^{a}$ Calculations are based on the average percentage of CRs across all $10 \mathrm{~d}$ of paired CS-UCS training, irrespective of CS modality. The mean percentages of CRs of vehicle-injected animals on which these calculations are based were, for study 1 , $41.7 \%$ CRs; for study $2,54.8 \%$ CRs.

${ }^{b} p<0.05$, as compared with vehicle controls.

low for vehicle controls $(2.7 \%)$ and not significantly different from their baseline rate of responding (1.0\%). Animals injected with L-PIA $(5.0 \mu \mathrm{mol} / \mathrm{kg})$ also demonstrated low levels of responding to tone and light stimuli $(2.0 \%)$ and baseline responding $(1.8 \%)$, which were not significantly different from the values for vehicle controls. Moreover, there was no significant change in the percentages of responding to tone and light stimuli or in baseline responding across the $10 \mathrm{~d}$ of training, and these low percentages of responding (1.0-2.7\%) were not significantly different from responding during adaptation $(0.6 \%)$, when no stimuli were presented and no drug or vehicle injected. The amplitude of the UCR elicited by the $3.0 \mathrm{~mA}$ shock UCS across all $10 \mathrm{~d}$ of the unpaired stimulus procedure was $4.8 \pm 0.8 \mathrm{~mm}$ of membrane extension for vehicle controls, which was not significantly different from that of animals receiving L-PIA (3.7 \pm $0.5 \mathrm{~mm}$ ). L-PIA also had no significant effect on the onset latencies of the UCRs (data not shown). It should be noted that both control and L-PIA injected animals demonstrated 100\% responding to the UCS across all $10 \mathrm{~d}$ of training.

L-PIA does not affect the elicitation of UCRs by the shock UCS Figure 3 presents the percentage of UCRs $(A)$ and UCR amplitudes $(B)$ as a function of shock UCS intensity across $3 \mathrm{~d}$ of testing of rabbits receiving vehicle or $5.0 \mu \mathrm{mol} / \mathrm{kg}$ of L-PIA. Animals injected with L-PIA showed no consistent or significant difference from vehicle controls in the percentage of UCRs elicited at any UCS intensity (Fig. $3 A$ ). A UCS-intensity threshold was calculated separately for each animal by interpolating the shock intensity at which UCRs would have occurred on $50 \%$ of the trials. There was no significant difference between the shock-intensity thresholds of vehicle controls $(0.80 \pm 0.10 \mathrm{~mA})$ and animals injected with $5 \mu \mathrm{mol} / \mathrm{kg} \mathrm{L}$-PIA $(0.78 \pm 0.11 \mathrm{~mA})$. Finally, in agreement with the results of the study in which the unpaired stimuli were prescnted, L-PIA produced only small and nonsignificant decreases in UCR amplitude (Fig. $3 B$ ) and no significant effects on UCR-onset latency (data not shown).

L-PIA blocks the elicitation of CRs by a tone CS

Prior to the measurement of the tone-CS threshold for elicitation of CRs, rabbits had received $7 \mathrm{~d}$ of acquisition training con-

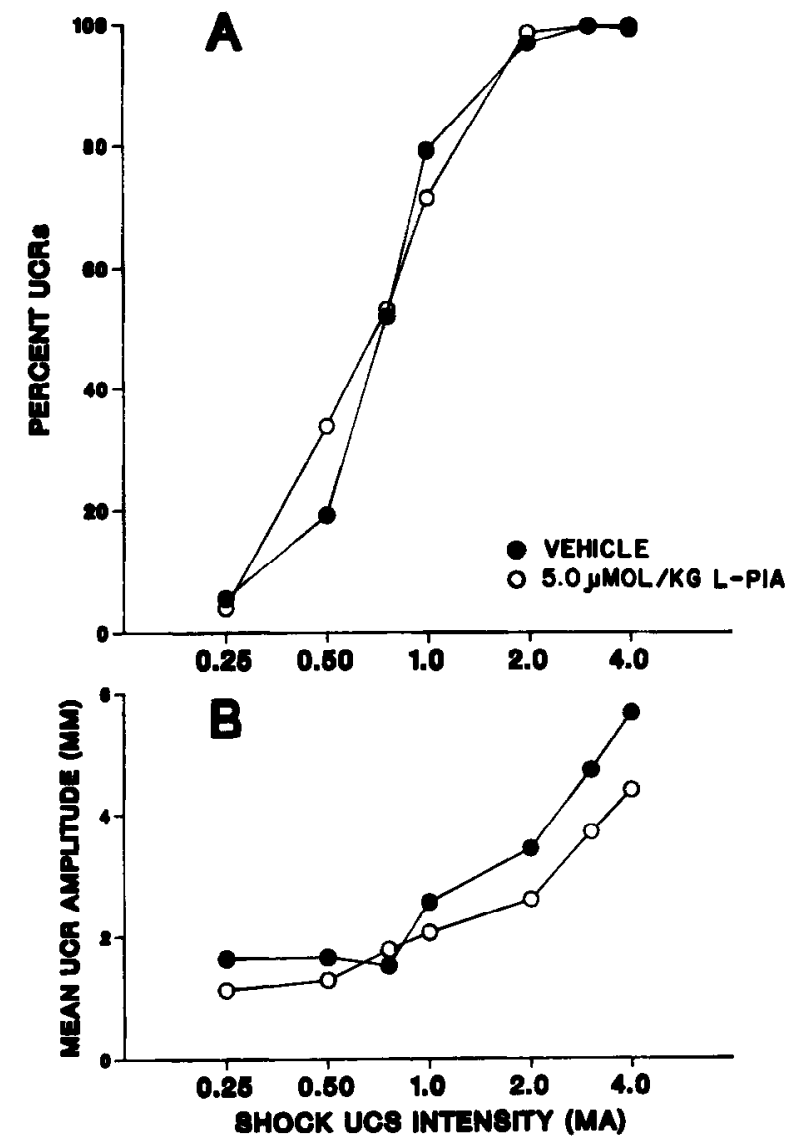

Figure 3. Effects of $5.0 \mu \mathrm{mol} / \mathrm{kg}$ L-PIA on the mcan percentage of UCRs $(A)$ and UCR amplitudes $(B)$ across a range of shock-UCS intensities presented in experiment 4. Rabbits received subcutaneous injections 5-15 min prior to each of 3 sessions. Data are based on the means of 12 rabbits/group across all $3 \mathrm{~d}$ of testing.

sisting of the pairing of an $84 \mathrm{~dB}$ tone CS with a $3 \mathrm{~mA}$ shock UCS, during which time no drug or vehicle was injected. By the last (seventh) conditioning session, animals that were to receive vehicle and L-PIA $(5.0 \mu \mathrm{mol} / \mathrm{kg})$ had achieved comparable levels of responding -92 and $89 \%$ CRs, respectively. Figure 4 presents the results obtained when these animals were then tested for CRs by varying the intensities of the tone CS.

As expected from previous studies (Scavio and Gormezano, 1974), the percentage of CRs for vehicle controls decreased with decreasing intensities of the tone CS (Fig. 4). More important, L-PIA $(5.0 \mu \mathrm{mol} / \mathrm{kg})$ significantly $(p<0.01)$ blocked the ability of the tone CS to elicit CRs. Vehicle controls demonstrated high levels of conditioned responding $(98 \%)$ at the original training intensity of the tone $\mathrm{CS}(84 \mathrm{~dB})$, as well as at the 2 lower intensities of 80 and $75 \mathrm{~dB}$; these levels of responding were comparable to those seen in vehicle controls on the last (seventh) day of training $(92 \%)$. In contrast, L-PIA $(5.0 \mu \mathrm{mol} / \mathrm{kg})$ produced a significant reduction in the percentage of CRs elicited by the original training intensity of the CS $(56 \%$, as compared with $89 \%$ on the last day of original training) and significantly fewer CRs than vehicle controls across all CS intensities from 50 to $84 \mathrm{~dB}$ ( $p<0.01$ for all comparisons). For vehicle controls, the percentage of CRs elicited by CS intensities of $45 \mathrm{~dB}$ or higher was significantly greater than baseline responding $(p<0.05)$, while for L-PIA injected animals tone intensities of $70 \mathrm{~dB}$ or greater were required to elicit a percentage of responding significantly above their baseline level. 


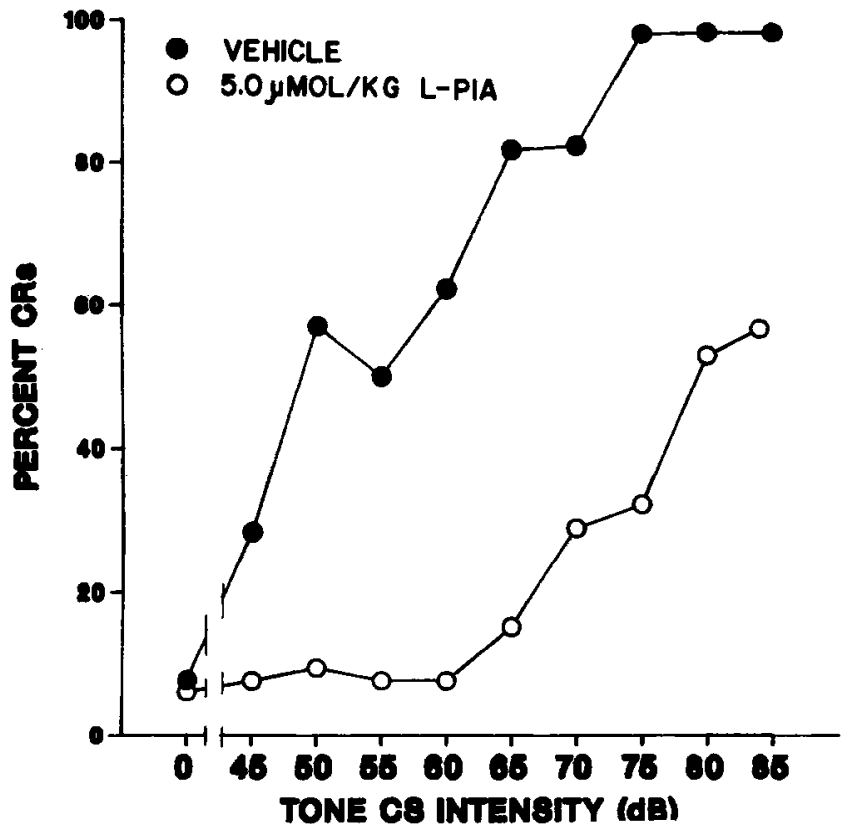

Figure 4. Effects of $5.0 \mu \mathrm{mol} / \mathrm{kg}$ of L-PIA on the mean percentage of conditioned responses across a range of tone CS intensities presented in experiment 5 . Rabbits received $7 \mathrm{~d}$ of 60 tone- $(84 \mathrm{~dB})$ shock $(3 \mathrm{~mA})$ pairings, followed by 1 additional day of training in which the tone intensity was varied between 45 and $84 \mathrm{~dB}$. Five to $15 \mathrm{~min}$ prior to this last training day, rabbits received subcutaneous injections of vehicle $(n=10)$ or L-PIA $(n=11)$.

\section{Discussion}

\section{L-PIA blocked associative learning by reducing the excitatory properties of the tone $C S$}

In agreement with numerous studies that have employed classical (Pavlovian) conditioning of the nictitating membrane response in control rabbits (Gormezano et al., 1983), the acquisition of CRs to tone and light CSs by the vehicle-injected animals of this study provided an unambiguous measure of associative learning. For example, rabbits receiving explicitly unpaired presentations of tone, light, and shock stimuli demonstrated low levels of nonassociative responding $(<3 \%)$ that did not change across the $10 \mathrm{~d}$ of training and were not significantly different from baseline responding observed during adaptation, when no stimuli were presented. Therefore, the acquisition of CRs to tone and light CSs by vehicle-injected animals reflected associative learning, i.e., was primarily due to the temporal pairings of CS and UCS and was not contaminated by nonassociative contributors to $\mathrm{CR}$ production, such as sensitization, pseudoconditioning, or increases in baseline responding. Since L-PIA produced a dose-dependent and significant retardation in CR acquisition without affecting nonassociative responding, we can conclude that L-PIA was retarding associative learning.

The effects of L-PIA on associative learning could have resulted from an effect on the unconditioned and/or conditioned nictitating membrane reflex. The results obtained from the unpaired stimulus procedure and the shock-UCS threshold study indicated that L-PIA $(5.0 \mu \mathrm{mol} / \mathrm{kg})$ retarded CR acquisition without having any significant effect on the ability of the shock UCS to elicit the unconditioned reflex, or on the amplitude of the elicited UCR. In contrast, L-PIA $(5.0 \mu \mathrm{mol} / \mathrm{kg})$ produced a large and significant decrease in the ability of the tone CS to elicit the conditioned nictitating membrane reflex, which appeared to be due to an effect on the excitatory properties of the tone CS rather than on the motoric expression of the CR. This conclusion is based on the fact that both the CR and UCR result from activation of the same final common pathway. For example, extension of the nictitating membranc to a tone CS or shock UCS involves activation of retractor bulbi motoneurons located in the accessory abducens nucleus, with the consequent contraction of the retractor bulbi muscle via the VIth cranial nerve which, in turn, pulls the eye back into the orbit; the force of this mechanical action squeezes the nictitating membranc out over the cornea (Cegavske et al., 1976; Gray et al., 1981; Harvey et al., 1983a, 1984; Marek et al., 1984; Prince, 1964). Since L-PIA failed to affect the motoric expression of the UCR via this final common pathway, one can conclude that the motoric expression of the CR was also not affected. However, the precise anatomical locus at which L-PIA could have blocked the ability of the CS to elicit CRs remains unclear.

A number of drugs having effects on different transmitter systems alter the rate of CR acquisition through a change in the excitatory properties of the tone CS in a manner identical to that obtained with L-PIA (Harvey and Gormezano, 1986; Schindler et al., 1985). For example, haloperidol, scopolamine, morphine, and other opioids block both the acquisition of CRs and the ability of the CS to elicit CRs once learning has occurred, while $d$-lysergic acid diethylamide enhances both $C R$ acquisition and the ability of the CS to elicit CRs (Gormezano and Harvey, 1980; Harvey and Gormezano, 1981; Harvey et al., 1983b, 1985; Schindler et al., 1983, 1984, 1985). The basis for this common behavioral effect of L-PIA and other drugs on the excitatory properties of the CS is not clear, but may be related to the known interactions of L-PIA and adenosine on the physiological, biochemical, and behavioral effects of a variety of CNS drugs (Daly, 1979; Phillis, 1984; Phillis and Wu, 1982).

The retardant effect of $L-P I A$ on $C R$ acquisition appears to be mediated by an adenosine receptor

L-PIA has been identified as a highly potent adenosine agonist on the basis of the similarity between its effects and those of adenosine on a variety of physiological, biochemical, and behavioral processes (Cooper et al., 1980; Dunwiddie and Fredholm, 1984; Snyder et al., 1981). In addition, the majority of effects produced by L-PIA and adenosine appear to be centrally mediated, and it has been suggested that they result from an action at the Al receptor (Katims et al., 1983; Snyder, 1985). This conclusion was based on the order of potency of adenosine and L-PIA in producing an inhibition of neuronal firing, transmitter release, and adenylate cyclase activity, as well as decreases in locomotor activity and operant responding, and was consistent with their binding properties at the high-affinity $\mathrm{Al}$, but not at the low-affinity A2, adenosine receptor (Dunwiddie and Fredholm, 1984; Goldberg et al., 1985; Murray et al., 1982; Snyder et al., 1981; Wojcik and Neff, 1983). Moreover, L-PIA has been shown to be more potent than D-PIA in producing these physiological, biochemical, and behavioral effects, which is consistent with the high degree of stereoselectivity of the Al adenosine receptor for L-PIA, as compared with D-PIA (Goldberg et al., 1985; Londos and Wolff, 1977; Snyder et al., 1981; van Calker et al., 1979; Vapaatalo et al., 1975). Although the greater potency of L-PIA, compared to D-PIA, in classical conditioning in the present study would be consistent with an action at the $\mathrm{A} 1$ adenosine receptor, in the absence of specific $\mathrm{Al}$ and A2 antagonists conclusions based on potency differences may be misleading (Phillis and Barraco, 1985).

The retardation of CR acquisition produced by L-PIA could have resulted from either a decrease in the release of a variety of transmitters and/or effects on adenylate cyclase (Snyder, 1985). The ability of L-PIA to modulate cAMP levels either directly through the $A 1$ and $A 2$ adenosine receptors or indirectly through 
its interactions with other transmitter systems is of special interest. A number of investigators have suggested that the longterm changes in neural activity responsible for the occurrence of learning may be mediated by the intracellular second messenger, cAMP, through its catalytic effects on the phosphorylation of intracellular proteins by specific protein kinases (Greengard and Kuo, 1970; Kandel and Schwartz, 1982; McIlwain, 1977; Nathanson, 1977; Phillis, 1977). Evidence has been presented that long-term, nonassociative changes in behavior, such as sensitization and habituation of the defensive withdrawal reflex in Aplysia, are mediated by cAMP through the phosphorylation of proteins that alter ion channels and hence the excitability of the neuron (Brunelli et al., 1978; Klein and Kandel, 1980). Similar mechanisms for the occurrence of associative learning have subsequently been proposed (Kandel and Schwartz, 1982).

The widespread effects of adenosine on synaptic transmission have led to the suggestion that it may serve as an endogenous modulator of neural activity in the brain (Phillis and Kostopoulos, 1975; Snyder, 1985). The results obtained in the present study with the adenosine agonist, L-PIA, further suggest that adenosine may also serve as an endogenous modulator of associative learning.

\section{References}

Brunelli, M., V. Castellucci, and E. R. Kandel (1978) Synaptic facilitation and behavioral sensitization in Aplysia: Possible role of serotonin and cyclic AMP. Science 194: 1178-1181.

Cegavske, C. F., R. F. Thompson, M. M. Patterson, and I. Gormezano (1976) Mechanisms of efferent neuronal control of the reflex nictitating membrane response (Oryctolagus cuniculus). J. Comp. Physiol. Psychol. 91: 411-423.

Cooper, D. M. F., C. Londos, and M. Rodbell (1980) Adenosine receptor-mediated inhibition of rat cerebral cortical adenylate cyclase by a GTP-dependent process. Mol. Pharmacol. 18: 598-601.

Corradetti, R., G. Lo Conte, F. Moroni, M. B. Passani, and G. Pepeu (1984) Adenosine decreases aspartate and glutamate release from rat hippocampal slices. Eur. J. Pharmacol. 104: 19-26.

Daly, J. W. (1979) Adenosine and cyclic adenosine monophosphategenerating systems in brain tissue. In Physiological and Regulatory Functions of Adenosine and Adenine Nucleotides, H. P. Baer and G. I. Drummond, eds., pp. 229-241, Raven, New York.

Dunwiddie, T. V., and B. B. Fredholm (1984) Adenosine receptors mediating inhibitory electrophysiological responses in rat hippocampus are different from receptors mediating cyclic AMP accumulations. Naunyn Schmiedebergs Arch. Pharmacol. 326: 294-301.

Dunwiddie, T. V., and T. Worth (1982) Sedative and anticonvulsant effects of adenosine analogs in mouse and rat. J. Pharmacol. Exp. Ther. 220: 70-75.

Fredholm, B. B., and P. Hedqvist (1980) Modulation of neurotransmission by purine nucleotides and nucleosides. Biochem. Pharmacol. 29: $1635-1643$.

Glowa, J. R., and R. D. Spealman (1984) Behavioral effects of caffeine, $N^{6}$-(L-phenylisopropyl)adenosine and their combination in the squirrel monkey. J. Pharmacol. Exp. Ther. 231: 665-670.

Goldberg, S. R., J. A. Prada, and J. L. Katz (1985) Stereoselective behavioral effects of $N^{6}$-phenylisopropyl adenosine and antagonism by caffeine. Psychopharmacology 87: 272-277.

Goodman, R. F., and S. H. Snyder (1982) Autoradiographic localization of adenosine receptors in rat brain using $(3 \mathrm{H})$ cyclohexyladenosine. J. Neurosci. 2: 1230-1241.

Gormezano, I. (1966) Classical conditioning. In Experimental Methods and Instrumentation in Psychology, J. B. Sidowski, ed., pp. 385420, McGraw-Hill, New York.

Gormezano, I., and J. A. Harvey (1980) Sensory and associative effects of LSD in classical conditioning of rabbit (Oryctolagus cuniculus) nictitating membrane response. J. Comp. Physiol. Psychol. 94: 641649.

Gormezano, I., E. J. Kehoe, and B. S. Marshall (1983) Twenty years of classical conditioning with the rabbit. In Progress in Psychobiology and Physiological Psychology, Vol. 10, J. M. Sprague and A. N. Epstein, eds., pp. 197-275, Academic, New York.
Gray, T. S., S. E. McMaster, J. A. Harvey, and I. Gormezano (1981) Localization of retractor bulbi motoneurons in the rabbit. Brain Res. 226: 93-106.

Greengard, P., and J. F. Kuo (1970) On the mechanism of action of cyclic AMP. Adv. Biochem. Psychopharmacol. 3: 287-306.

Harvey, J. A., and I. Gormezano (1981) Effect of haloperidol and pimozide on classical conditioning of the rabbit nictitating membrane response. J. Pharmacol. Exp. Ther. 218: 712-719.

Harvey, J. A., and I. Gormezano (1986) The assessment of drug effects on learning and stimulus processing by means of classical conditioning. In Advances in Behavioral Pharmacology, Vol. 6, N. A. Krasnegor, D. B. Gray, and T. Thompson, eds., pp. 115-132, Erlbaum, New York.

Harvey, J. A., I. Gormezano, and V. A. Cool-Hauser (1985) Relationship between heterosynaptic reflex facilitation and acquisition of the nictitating membrane response in control and scopolamine-injected rabbits. J. Neurosci. 5: 596-602.

Harvey, J. A., T. Land, and S. E. McMaster (1984) Anatomical study of the rabbit's corneal-VIth nerve reflex: Connections between cornea, trigeminal sensory complex, and the abducens and accessory abducens nuclei. Brain Res. 301: 307-321.

Harvey, J. A., G. J. Marek, A. M. Johannsen, S. E. McMaster, T. Land and I. Gormezano (1983a) Role of the accessory abducens nucleus in the nictitating membrane response of the rabbit. Soc. Neurosci. Abstr. 9: 330.

Harvey, J. A., I. Gormezano, and V. A. Cool (1983b) Effects of scopolamine and methylscopolamine on classical conditioning of the rabbit nictitating membrane response. J. Pharmacol. Exp. Ther. 225: 42-49.

Jonzon, B., and B. B. Fredholm (1984) Adenosine receptor mediated inhibition of noradrenaline release from slices of the rat hippocampus. Life Sci. 35: 1971-1979.

Kandel, E. R., and J. H. Schwartz (1982) Molecular biology of learning: Modulation of transmitter release. Science 218: 433-443.

Katims, J. I., Z. Annau, and S. H. Snyder (1983) Behavioral interactions between methylxanthines and adenosine derivatives. J. Pharmacol. Exp. Ther. 227: 167-173.

Klein, M., and E. R. Kandel (1980) Presynaptic modulation of voltage dependent $\mathrm{Ca}^{2+}$ current: Mechanism for behavioral sensitization in Aplysia californica. Proc. Natl. Acad. Sci. USA 75: 3512-3516.

Londos, C., and J. Wolff (1977) Two distinct adenosine-sensitive sites on adenylate cyclase. Proc. Natl. Acad. Sci. USA 74: 5482-5486.

Londos, C., D. M. F. Cooper, and J. Wolff (1980) Subclasses of external adenosine receptors. Proc. Natl. Acad. Sci. USA 77: 2551-2554.

Logan, L., and J. M. Carney (1984) Antagonism of the behavioral effects of $L$-phenylisopropyladenosine (L-PIA) by caffeine and its metabolites. Pharmacol. Biochem. Behav. 21: 375-379.

McIlwain, H. (1977) Extended roles in the brain for second-messenger systems. Neuroscience 2: 357-372.

Marek, G., S. E. McMaster, I. Gormezano, and J. A. Harvey (1984) The role of the accessory abducens nucleus in the rabbit nictitating membrane response. Brain Res. 299: 215-229.

Murray, T. F., W. T. Blaker, D. L. Cheney, and E. Costa (1982) Inhibition of acetylcholine turnover rate in rat hippocampus and cortex by intraventricular injection of adenosine analogs. J. Pharmacol. Exp. Ther. 222: 550-544.

Nathanson, J. A. (1977) Cyclic nucleotides and nervous system function. Physiol. Rev. 57: 157-256.

Phillis, J. W. (1977) The role of cyclic nucleotides in the CNS. Can. J. Neurol. Sci. 152: 153-195.

Phillis, J. W. (1984) Adenosine's role in the central actions of the benzodiazepines. Prog. Neuropsychopharmacol. Biol. Psychiatry 8: 495-502.

Phillis, J. W., and R. A. Barraco (1985) Adenosine, adenylate cyclase, and transmitter release. In Advances in Cyclic Nucleotide and Protein Phosphorylation Research, Vol. 19, D. M. F. Cooper and K. B. Seamon, eds., pp. 243-258, Raven, New York.

Phillis, J. W., and G. K. Kostopoulos (1975) Adenosine as a putative transmitter in the cerebral cortex. Studics with potentiators and antagonists. Life Sci. 17: 1085-1094.

Phillis, J. W., and P. H. Wu (1982) The effect of various centrally active drugs on adenosine uptake by the central nervous system. Comp. Biochem. Physiol. 72: 179-187.

Phillis, J. W., J. P. Edstrom, G. K. Kostopoulos, and J. R. Kirkpatrick (1979) Effects of adenosine and adenine nucleotides on synaptic 
transmission in the cerebral cortex. Can. J. Physiol. Pharmacol. 57: $1289-1312$.

Prince, J. H. (1964) The Rabbit in Eye Research, Charles C Thomas, Springfield, IL.

Radulovacki, M., R. S. Miletich, and R. D. Green (1982) $N^{6}$-(L-phenylisopropyl) adenosine (L-PIA) increases slow-wave sleep (S2) and decreases wakefulness in rats. Brain Res. 246: 178-180.

Scandrett, J., and I. Gormezano (1980) Microprocessor control and A/D data acquisition in classical conditioning. Behav. Res. Methods Instrum. 12: 121-125.

Scavio, M. J., and I. Gormezano (1974) CS intensity effects upon rabbit nictitating membrane conditioning, extinction, and generalization. Pavlov. J. Biol. Sci. 9: 25-34.

Schindler, C. W., I. Gormezano, and J. A. Harvey (1983) Effect of morphine on acquisition of the classically conditioned nictitating membrane response of the rabbit. J. Pharmacol. Exp. Ther. 227: 639643.

Schindler, C. W., I. Gormezano, and J. A. Harvey (1984) Sensory and associative effects of morphine and naloxone in classical conditioning of the rabbit nictitating membrane response. Psychopharmacology 83: 114-121.
Schindler, C. W., I. Gormezano, and J. A. Harvey (1985) Effects of drugs on classical conditioning. In Behavioral Pharmacology: The Current Status, L. S. Seiden and R. L. Balster, eds., pp. 55-71, Alan R. Liss, New York.

Snyder, S. H. (1985) Adenosine as a neuromodulator. Annu. Rev. Neurosci. 8: 103-124.

Snyder, S. H., J. J. Katims, Z. Annau, R. F. Bruns, and J. W. Daly (1981) Adenosine receptors and behavioral actions of methylxanthines. Proc. Natl. Acad. Sci. USA 78: 3260-3264.

van Calker, D., M. Muller, and B. Hamprecht (1979) Adenosine regulation via two types of receptors: The accumulation of cyclic AMP in cultured brain cells. J. Neurochem. 33: 999-1005.

Vapaatalo, H., D. Onken, P. J. Neuvonen, and E. Westermann (1975) Stereospecificity in some central and circulatory effects of phenylisopropyl-adenosine (PIA). Arzheimforsch. 25: 407-410.

Winer, B. J. (1971) Statistical Principles in Experimental Design, McGraw-Hill, New York.

Wojcik, W. J., and N. H. Neff (1983) Adenosine A1 receptors are associated with cerebellar granule cells. J. Neurochem. 41: 759-763. 